\title{
Penerapan Metode Demonstrasi Untuk Meningkatkan Hasil Belajar Pendidikan Agama Islam Pada Siswa Kelas X Di SMK Negeri 2 Paguyaman
}

\author{
ASMA \\ Guru SMK Negeri 2 Paguyaman \\ asma@gmail.com \\ Received: 04 March 2021; Revised: 26 April 2021; Accepted: 28 July 2021 \\ DOI: http://dx.doi.org/10.37905/aksara.7.3.1135-1142.2021
}

\begin{abstract}
ABSTRAK:
Penelitian ini menggunakan metode kualitatif Penelitian Tindakan Kelas (PTK). Populasi penelitian ini adalah siswa Kelas X di SMK Negeri 2 Paguyaman tahun pelajaran 2018/2019. Teknik pengambilan data yang digunakan adalah observasi penelitian wawancara.

Dari penelitian ini ditemukan bahwa implementasi pembelajaran wudhu di SMK Negeri 2 Paguyaman termasuk dalam kategori baik. Hal ini ditunjukan oleh kemampuan guru dalam menjalankan peran dan fugsinya untuk mengelola pembelajaran. Khususnya implementasi pembelajaran wudhu.

Berdasarkan hasil penelitian yang dilakukan terkait dengan upaya meningkatkan hasil belajar siswa melalui penerapan model pembelajaran demonstrsi pada implementasi pembelajaran wudhu, maka dapat disimpulkan bahwa terdapat peningkatan hasil belajar siswa setelah dilakukannya pembelajaran dengan menerapkan model pembelajaran demonstrasi.

Hal tersebut dapat dilihat dari hasil yang diperoleh berdasarkan tindakan yang telah diberikan kepada siswa Kelas X SMK Negeri 2 Paguyaman. Dapat disimpulkan bahwa hasil belajar siswa pada siklus I dan Siklus II mengalami peningkatan. Pada siklus I rata-rata nilai pre test siswa 67,8 meningkat menjadi 69,95 pada nilai post test tetapi belum 100\% siswa mencapai nilai KKM. Sedangkan hasil belajar siswa pada siklus II lebih baik dari siklus I yaitu nilai rata-rata pre test siswa 76,55 menjadi 83,52pada nilai post test. Dan jumlah siswa yang mencapai nilai KKM sudah $100 \%$.
\end{abstract}

Kata Kunci : metode demonstrasi, hasil belajar siswa, PAI

\section{PENDAHULUAN}

Pendidikan Islam merupakan satu diantara sarana pembudayaan (enkulturasi) masyarakat. Ajaran Islam tidak hanya membahas mengenai satu aspek saja, tetapi mencakup semua aspek yang lain, sehingga dengan pendidikan Islam pola hidup dan perilaku masyarakat menjadi terarah sesuai dengan ajaran dan nilai-nilai yang luhur. Sebagai suatu sarana, pendidikan dapat difungsikan untuk mengarahkan pertumbuhan dan perkembangan hidup manusia (sebagai makhluk pribadi dan sosial) kepada harapan dan tujuam yamg merupakan titik optimal kemampuan seorang hamba yaitu untuk 
memperoleh kesejahteraan hidup baik lahir maupun batin di dunia dan kebahagiaan hidup di akhirat.

Pendidikan yang paling penting bagi setiap manusia adalah pendidikan Islam. Pendidikan Islam bertujuan untuk menyempurnakan atau memperbaiki budi pekerti manusia menurut Islam, yang berlandaskan syariat Islam yang bersumber dari Al-Quran dan Hadits. ${ }^{3}$

Di dalam UU No. 20 Tahun 2003 tentang Sistem Pendidikan Nasional, dinyatakan bahwa pendidikan nasional berfungsi mengembangkan kemampuan dan membentuk watak serta peradaban bangsa yang bermartabat dalam rangka mencerdaskan kehidupan bangsa, bertujuan untuk berkembangnya potensi peserta didik agar menjadi manusia yang beriman dan bertaqwa kepada Tuhan Yang Maha Esa, berakhlak mulia, sehat, berilmu, cakap, kreatif, mandiri dan menjadi warga negara yang demokratis serta bertanggung jawab. ${ }^{4}$

Di dalam UU No. 2 Tahun 2008 tentang standar kompetensi lulusan dan standar isi pendidikan agama Islam dan bahasa arab diMadrasah. Kurikulum di dalam Madrasah Ibtidaiyah terdiri dari Al-Quran dan Hadits, akidah akhlaq, fikih, sejarah kebudayaan Islam, bahasa arab. ${ }^{5}$

Pendidikan Agama Islam adalah suatu usaha yang sistematis dan pragmatis dalam membimbing anak didik, sehingga ajaran agama islam benar-benar dapat menjiwai bagian yang integral dalam pribadinya. Pendidikan Agama Islam pun diberikan kepada peserta didik di bangku sekolah, selain itu untuk menanamkan pendidikan Agama Islam juga dimulai dari keluarga, lingkungan dan masyarakat yang baik. Salah satu ajaran pendidikan Agama Islam adalah wudhu.

Wudhu adalah sifat yang nyata (suatu perbuatan yang dilakukan dengan anggotaanggota badan yang tertentu) yang dapat menghilangkan hadas kecil yang ada hubungannya dengan shalat.

Realitanya di sekolah masih banyak anak yang belum mengetahui pengertian wudhu, wajib wudhu dan sunnah wudhu.Seorang guru fiqih mengatakan bahwa masih banyak anak yang belum mengerti tentang wudhu beliau mengatakan "wudhu merupakan penyempurna bersuci atau thaharah ketika seorang muslim ingin melakukan ibadah ritual (shalat)" ". Pendapat tersebut belum sesuai dengan apa yang diharapkan oleh guru fiqih di sekolah.

Dengan ini penulis akan melakukan penelitian dengan metode demonstrasi. Adapun metode demonstrasi adalah suatu upaya pembelajaran atau proses belajar dengan cara praktek menggunakan peragaan yang di tujukan pada siswa dengan tujuan agar semua siswa lebih mudah dalam memahami dan mempraktekkan apa yang telahdiperolehnya dan dapat mengatasi suatu permasalahan yang terjadi sehubungan dengan yang sudah didemonstrasikan.

Untuk mendapatkan hasil yang maksimal seorang guru agama islam mengatakan harus ada kerjasama antara guru dan orang tua,karena pembelajaran wudhu di sekolah hanya beberapa kali pertemuan, sedangkan di rumah anak-anak dapat belajar setiap waktu bila hendak mengerjakan shalat.

Berdasarkan uraian diatas dan mengingat pentingnya melaksanakan ibadah wudhu, maka penulis tertarik untuk menelaah menganai "Peningkatan hasil belajar implementasi pembelajaran wudhu Kelas X di SMK Negeri 2 Paguyaman melalui metode demonstrasi. 


\section{METODE PENELITIAN}

Penelitian ini dilaksanakan di Kelas X SMK Negeri 2 Paguyaman, yang berlokasi di Jalan Trans Sulawesi Pohuwato. Waktu penelitian dilaksanakan pada semester II tepatnya mulai bulan Maret sampai dengan bulan April 2019.

Metode penelitian tindakan kelas ini dilakukan pada mata pelajaran Fiqih dengan menggunakan pendekatan pembelajaran metode demonstrasi untuk meningkatkan motivasi belajar PAI siswa.

Model penelitian tindakan yang digunakan dalam penelitian ini adalah desain PTK model Kurt Lewin. Model ini terdiri atas empat komponen, yaitu perencanaan (planning), tindakan (acting), pengamatan (observing), dan refleksi (reflecting). Hubungan keempat komponen tersebut dipandang sebagai satu siklus.

Teknik pengumpulan data dalam penelitian ini adalah: Melakukan observasi terhadap aktivitas siswa yang diisi oleh observer dan peneliti. Menyiapkan lembar penilaian siswa untuk mengisi nilai pada tiap akhir siklus. Mendokumentasikan kegiatan pembelajaran, dokumentasi yang dimaksudadalah foto-foto yang diambil pada saat pmbelajaran berlangsung oleh penelitiSetelah data diperoleh, peneliti berkolaborasi dengan guru Fiqih untuk melakukan analisis dan evaluasi data untuk mengambil kesimpulan tentang peningkatan motivasi belajar, aktivitas belajar dan hasil belajar siswa serta membahas tentang kekurangan dan kelebihan penelitian tindakan kelas yang telah dilakukan.

Dalam melakuan penelitian ini, peneliti membuat pengembangan perencanaan tindakan agar dapat menjadi referensi bagi guru atau pembaca. Untuk keperluan ini, peneliti menyiapkan instrument penelitian seperti lembar observasi, lembar penilaian, RPP. Penelitian ini berkahir apabila telah berhasil menguji penggunaan demonstrasi dalam meningkatkan motivasi belajar Fiqih terutama dalam berwudhu siswa.

\section{HASIL DAN PEMBAHASAN}

Penelitian tindakan kelas ini di mulai dengan melakukan observasi awal di SMK Negeri 2 Paguyaman. Sebelum diadakan penelitian, penulis melakukan analisis kebutuhan terlebih dahulu. Dari analisis kebutuhan diperoleh gambaran mengenai situasi dan kondisi belajar tempat penelitian diadakan. Analisis kebutuhan kegiatan ini meliputi wawancara dengan guru mata pelajaran agama islam dan siswa Kelas X. Serta melakukan observasi aktivitas siswa dalam proses pembelajaran figh. Kegiatan ini bertujuan untuk mengetahui aktivitas siswa dalam proses pembelajaran, serta hasil belajar yang diperoleh selama proses pembelajaran agama islam di SMK Negeri 2 Paguyaman.

Peneliti melakukan wawancara pada tanggal 19 Maret 2019, Pukul 10.45, bertempat di ruang guru. Wawancara ini bertujuan untuk mengetahui proses pembelajaran fiqih di SMK Negeri 2 Paguyaman dan mengetahui hasil belajar agama islam siswa. Berdasarkan wawancara tersebut diperoleh informasi bahwa metode pembelajaran agama islam yang selama ini digunakan adalah dengan metode ceramah, tanya jawab, serta pembelajaran lebih menitik beratkan pada pengerjaan tugas LKS yang banyak. Guru menganggap gaya belajar masing-masing siswa berbeda-beda sehingga membuat guru sukar menemukan metode pembelajaran yang tepat yang disukai oleh siswa. Selain itu sikap siswa cenderung pasif dalam belajar agama islam sehingga kurang adanya interaksi antara guru dan siswa, yang berujung pada hasil belajar agama islam siswa yang rendah, terutama pada materi implementasi pembelajaran wudhu. Kemudian 
guru pun jarang menggunakan media serta alat-alat yang menunjang dalamproses pembelajaran agama islam, salah satu kendalanya adalah fasilitas yang kurang memadai.

Dari hasil wawancara ini, ditentukan Kelas X sebagai kelas yang cocok untuk diadakan penelitian, terkait dengan permasalahan hasil belajar siswa dalam pembelajaran agama islam. Dalam pengamatan ini terlihat sikap siswa dari sebagian besar siswa di kelas kurang memiliki prestasi yang lebih dibandingkan dengan kelas lain. Hal ini terlihat dari hasil pelaksanaan pembelajaran wudhu siswa masih banyak yang belum dapat melaksanakan wudhu dengan baik dan benar. Dalam proses pembelajaran, masih banyak siswa yang takut untuk bertanya pada guru, kemudian semangat belajar siswa pun kurang, dan tidak memperhatikan guru saat guru menerangkan.

Selanjutnya peneliti mewawancarai 15 orang siswa Kelas $\mathrm{X}$ yang dijadikan sebagai sampel untuk mengetahui bagaimana proses pembelajaran agama islam di kelas. 15 orang siswa yang dipilih untuk di wawancarai berdasarkan peringkat di kelas, 8 siswa peringkat teratas, dan 7 siswa peringkat terbawah, terutama pada mata pelajaran agama islam. Tujuan wawancara dengan siswa adalah untuk mengetahui kendala-kendala yang dihadapi dalam pembelajaran agama islam, faktor-faktor yang mempengaruhi proses belajar serta penggalian informasi tentang metode belajar yang diminati siswa. Dari hasil wawancara tersebut tercatat 9 orang siswa yang tidak menyukai pelajaran agama islam, dan 6 orang siswa kurang menyukai pelajaran agama islam. Alasan dari siswa yang kurang menyukai pelajaran agama islam adalah karena guru menjelaskan materi tidak jelas (ngambang), pada pembelajaran wudhu hanya teori saja yang disampaikan, sehingga siswa kesulitan dalam melaksanakan proses pembelajaran wudhu. Selain itu gaduh nya kelas dari beberapa orang siswa, yang mengakibatkan siswa lain sulit berkonsentrasi. Serta siswa merasa hasil belajar yang ia peroleh pada pelajaran agama islam tidak memuaskan.

Berdasarkan wawancara yang telah dilakukan pada guru mata pelajaran agama islam, serta siswa, dapat disimpulkan bahwa beberapa hambatan yang telah di paparkan diatas dapat menjadikan siswa menjadi malas untukmempelajari pelajaran agama islam, karena pembelajaran yang dilakukan masih konvensional dengan metode ceramah, serta pemberian tugas yang banyak, pembelajaran yang tidak berpusat pada siswa, yang dapat mengaktifkan siswa, dan pembelajaran bersifat text book. Serta kegaduhan kelas yang sering diciptakan oleh beberapa orang siswa yang membuat siswa lain menjadi tidak konsentrasi dalam belajar. Oleh karena itu tugas guru untuk mengatasi hambatanhambatan tersebut, dengan melakukan pembelajaran secara bervariasi, agar tidak terjadi kebosanan pada diri siswa karena merasa mata pelajaran agama islam sulit untuk dipelajari. Serta perbaikan pada pengelolaan kelas serta model pembelajaran yang diterapkan sangat baik dilakukan oleh guru. Tujuannya adalah untuk meningkatkan hasil belajar agama islam terutama pada proses implementasi pembelajaran wudhu siswa.

Selain dengan wawancara, peneliti melakukan observasi, observasi dilakukan sebelum penelitian, hasil observasi di catat dan terlampir. Observasi proses pembelajaran dilakukan pada tanggal 24 Februari 2015 dan diperoleh gambaran mengenai situasi dan kondisi belajar siswa serta kondisi lingkungan sekolah dan fasilitas penunjang proses belajar yang ada. Observasi dilakukan dengan cara mengamati langsung keadaan kelas pada saat proses belajar mengajar pada mata pelajaran agama islam.Hasil observasi diolah dengan cara mendeskripsikan hasil pengamatan. Hasil observasi ini dijadikan data 
tambahan dan data pelengkap dari data kuantitatif yang berupa hasil Pre Test dan Post Test.

Berdasarkan hasil observasi, dapat disimpulkan bahwa hasil belajar agama islam masih tergolong rendah. Banyak siswa beranggapan bahwa mata pelajaran agama islam adalah mata pelajaran yang membosankan dan sulit dalam hal implementasinya.Hal ini terbukti dengan hasil belajar yang diperoleh siswa tidak memuaskan. Selain itu ada berbagai hambatan yang dihadapi oleh Siswa Kelas X SMK Negeri 2 Paguyaman, diantaranya yaitu : kondisi kelas yang gaduh, yang mengurangi daya konsentrasi siswa dalam belajar, metode pembelajaran yang digunakan pun masih konvensional, yakni metode ceramah, serta pembelajaran yang dilakukan oleh guru bersifat text book, mengacu pada buku atau LKS. Dan dapat dikatakan seperti mendikte kan kalimatkalimat, serta pembelajaran tidak berpusat pada siswa yang dapat mengaktifkan siswa, sehingga siswa merasa jenuh pada saat proses pembelajaran, karena siswa tidak dapat menemukan sendiri materi pokok serta kata kunci (key word) yang penting. Dan pada saat proses pembelajaran berlansung ada beberapa orang siswa yang terlihat malas untuk belajar, hal ini ditunjukkan dengan sikap dan perilaku yang ditampilkan oleh siswa yang bersangkutan, seperti tidur di dalam kelas, bersenda gurau dengan teman, serta menunjukkan sikap yang antipati terhadap pembelajaran agama islam.

Berdasarkan hasil pengamatan peneliti, observasi dan wawancara situasi Kelas X tergolong dalam kelas yang ramai, dengan kriteria siswa yang berbeda-beda, ada yang pendiam dan ada yang aktif. Secara keseluruhan pembelajaran yang telah dilakukan pada siklus I dengan menerapkan model pembelajaran demonstrasi dalam kegiatan pembelajaran, metode ini dapat meningkatkan hasil belajar siswa, ini dapat telihat pada nilai Pre Test dan Post Test pada Siklus I.Pada pelaksanaan siklus 1 masih banyak kekuranganyang terjadi ketika siswa melaksankan praktek pembelajaran wudhu diantaranya: Masih banyak siswa yang melaksanakan wudhu tidak tertib (tidak berurutan),mendahulukan anggota yang kiri dari pada yang kanan, ketika membasuh anggota wudhu tidak tiga kali tetapi masih sembarangan dan menghambur-hamburkan air, tidak membaca doa ketika hendak berwudhu, tidak membaca doa ketika selesai berwudhu.

Siklus II mengalami peningkatan. Adapun aktivitas pembelajaran yang ditunjukkan oleh kegiatan siswa pada kegiatan implementasi pembelajaran wudhu dapat dikatakan baik, hal ini dapat dilihat ketika siswa melaksanakan wudhu sudah tertib ( berurutan ), mendahulukan yang kanan ketika membasuh anggota wudhu, menigakalikan dalam membasuh anggota wudhu, tidak menghambur-hamburkan air, membaca doa ketika hendak berwudhu, dan membaca doa ketika selesai berwudhu.

Dalam pembelajaran metode demonstrasi ini dapat meningkatkan hasil belajar siswa, ini dapat terlihat pada nilai Pre Test dan Post Test pada siklus I dan siklus II mengalami peningkatan. Adapun aktivitas pembelajaran yang ditunjukkan oleh kegiatan siswa pada siklus I dan siklus II dapat dikatakan baik, hal ini dapat dilihat dari setiap pertemuan dari siklus I ke siklus II. 


\section{PENUTUP}

Berdasarkan hasil penelitian yang dilakukan terkait dengan upaya meningkatkan hasil belajar siswa melalui penerapan model pembelajaran demonstrsi pada implementasi pembelajaran wudhu, maka dapat disimpulkan bahwa terdapat peningkatan hasil belajar siswa setelah dilakukannya pembelajaran dengan menerapkan model pembelajaran demonstrasi.

Hal tersebut dapat dilihat dari hasil yang diperoleh berdasarkan tindakan yang telah diberikan kepada siswa Kelas X SMK Negeri 2 Paguyaman. Dapat disimpulkan bahwa hasil belajar siswa pada siklus I dan Siklus II mengalami peningkatan. Pada siklus I rata-rata nilai pre test siswa 67,8 meningkat menjadi 69,95 pada nilai post test tetapi belum $100 \%$ siswa mencapai nilai KKM. Sedangkan hasil belajar siswa pada siklus II lebih baik dari siklus I yaitu nilai rata-rata pre test siswa 76,55 menjadi 83,52pada nilai post test. Dan jumlah siswa yang mencapai nilai KKM sudah $100 \%$.

Peningkatan hasil belajar yang terjadi dari Siklus I dan Siklus II disebabkan oleh beberapa faktor yaitu : Pertama, faktor siswa yang sudah mulai terbiasa menerapkan model pembelajaran demonstrasi hal ini disebabkan karena penerapan model pembelajaran demonstrasi dilakukan secara berulang dengan dua siklus yaitu siklus I dan siklus II sehingga siswa mulai terbiasa menerapkan model pembelajaran demonstrasi. Kedua, penerapan model pembelajaran demonstrasi pada siklus II lebih bervariatif dan lebih mengaktifkan siswa. Pada siklus I penerapan model pembelajaran demonstrasi hanya sebagian siswa saja yang dapat melaksanakan implementasi pembelajaran wudhu dengan baik dan benar, karena sebagian siswa lain masih belum dapat melaksanakan implementasi pembelajaran wudhu dengan benar, dan pada siklus II siswa sudah mulai terbiasa melaksanakan pembelajaran wudhu menggunakan model pembelajaran demonstrasi selain itu terdapat perbaikan-perbaikan cara kerja siswa dengan menggunakan model pembelajaran demonstrasi pada siklus II. Dan Ketiga siswa sudah terbiasa melaksanakan implementasi pembelajara wudhu dengan model pembelajaran demonstrasi. Ketiga faktor inilah yang membuat hasil belajar siswa meningkat pada siklus II. utama dalam keberhasilan belajar agama islam pada siswa Kelas X SMK Negeri 2 Paguyaman.Karena dengan menggunakan model pembelajaran demonstrasi siswa dituntut untuk aktif dalam kegiatan belajar sesuai dengan langkah-langkah model pembelajaran demonstrsi Masing-masing siswa dalam melaksanakan proses implementasi pembelajaran wudhu dapat dilaksanakan secara bergantian, pada saat siswa melaksanakan praktek pembelajaran wudhu siswa yang lain memperhatikan, peneliti hanya mengawasi, lain halnya pada siklus 1 peneliti selain mengawasi juga memberikan pengarahan tentang proses implementasi pembelajaran wudhu, berbeda pada siklus 2 peneliti hanya mengawasi saja karena siswa telah mengetahui proses implementasi pembelajaran wudhu model demonstrasi. Manfaat penggunaan model pembelajaran demonstrasi ini adalah mengetahui kesalahan yang dilaksankan siswa dalam proses implementasi pembelajaran wudhu yang selama ini dilaksanakan oleh siswa. 
DAFTAR PUSTAKA

Abd.Rozak, dkk, Kompilasi Undang-Undang dan Peraturan Bidang Pendidikan, Jakarta: FITK PRESS Fakultas Ilmu Tarbiyah dan Keguruan Uin Syarif Hidayatullah Jakarta, 2010.

Arikunto, Suharsini, Prosedur Penelitian, Jakarta: Rineka Cipta, 1992. , Prosedur Penelitian Suatu Pendekatan Praktek, Jakarta: Rineka Cipta, 2006.

Cipta, 2010.

Prosedur Penelitian Suatu Pendekatan Praktek, Jakarta: Rineka Prosedur Penelitian, Jakarta: Rineka Cipta, 2007

Daradjat, Zakiah, Ilmu Pendidikan Islam, Jakarta: Bumi Aksara, 1992

Dimyati., dan Mudjiono, Belajar dan Pembelajaran, Jakarta: Rineke Cipta, 2006

Hamalik, Oemar, Dasar-dasar Pengembangan Kurikulum, Jakarta: Remaja Rosdakarya, 2009.

Majid, Abdul, Perencanaan Pembbeljaran, Bandung: Remaja Rosdakarya, 2012.

Mardalis, Metode Penelitian, Jakarta: Bumi Aksara, 2003.

Margono, Metodologi Penelitian Pendidikan, Jakarta: Rineka Cipta, 2007.

Mihamzah, Karto, Wawancara awal dengan guru, 10-Januari-2015.

, Risalah Tuntunan Shalat Lengkap, Semarang: PT. Karya Toha Putra, 2006.

Munadi, Yudhi, Media Pembelajaran, Jakarta: Gaung Persada Press, 2008.

Ritonga, Rahman., dan Zainudin, Fiqih Ibadah, Jakarta: Gaya Media Pratama, 1997.

Sukmadinata, Saodih Nana, Metode Penelitian, Bandung: Remaja Rosda Karya, 2005.

Sumaryani, Andri, Wawancara awal dengan guru, 08-Januari-2015.

Wiriatmadja, Metode Penelitian Tindakan Kelas, Bandung: Remaja Rosda Karya, 2005. Zahrah, Abu Muhammad, Ushul Fiqih, Jakarta: PT Pustaka Firdaus, Jakarta, 2011.

Zayadi, Ahmad., dan Madjid Abdul, Tadzkirah, Jakarta: Raja Grafindo Persada, 2005. 
AKSARA: Jurnal Ilmu Pendidikan Nonformal

P-ISSN 2407-8018 E-ISSN 2721-7310 DOI prefix $\underline{10.37905}$

Volume 07, (03) September 2021

http://ejurnal.pps.ung.ac.id/index.php/Aksara

1142 AKSARA: Jurnal Ilmu Pendidikan Nonformal 